\title{
Introduction
}

\section{Donald Creighton and His Macdonald}

\section{P.B. WAITE}

Half a century ago the History Department at the University of Toronto inhabited a spacious old house at the corner of St. George and College streets that once belonged to Robert Baldwin, the Reform politician from the 1840 s and I 8 sos. Hence it was called Baldwin House. In I950-5I, in a large west room on the ground floor, for two hours Donald Creighton held his weekly graduate seminar in Canadian history, I 840 to 1900 . There were a dozen graduate students there that year, some of them war veterans, from several universities-Dalhousie, U.N.B., Queen's, Manitoba, U.B.C., as well as Toronto. The topic for discussion one January afternoon in I95 I was the Pacific Scandal, with a paper given by an M.A. student from western Canada. The paper was not all that good, a slapdash affair grubbed up from secondary sources, mostly from Sir Joseph Pope's biography of Macdonald published in I 894 . There was little use of primary sources, nothing from the Royal Commission Report on the scandal, nothing from the newspapers. Creighton, long, lean and pensive, presided at the head of the table.

In our experience he had always been fair. That he had opinions we knew, but he rarely obtruded them. He seemed to be after what had really happened; he neither wanted nor expected conformity with his own views. So he did not ride roughshod over student papers, bullying as Chester Martin, head of the department from 1928 to 1952 , was wont to do. Creighton respected evidence and taught us to do so also. You could tell him anything if you could prove it from the documents. He wanted you to reach 
for the truth, whatever that might be. But he did expect you to make the effort of reaching. Now, however, after fifteen minutes it was all too patent that this Pacific Scandal paper was thin and the effort put into it negligible. Creighton raised his hand. "I think," he said coolly and politely, "that we shall have to tidy this up a little." Creighton had never done this before; we sat silent, a little abashed that one of our number had, so to speak, let the side down.

We soon forgot our discomfort, however, and Creighton made no further mention of the matter. We soon forgot even the winter afternoon closing in outside. Creighton began to weave-there is no better word for it-the story of the Pacific Scandal, the railway negotiations, the struggle between Montreal and Toronto over C.P.R. control, the blackmail once the Americans got themselves in, how the Liberals bribed the clerk in J.J.C. Abbott's Montreal office, how he stole in and got at the files, pulled out the incriminating letters and telegrams and sidled out into the Montreal night, how they were published in the newspapers in July, I 873, and how Macdonald handled the whole messy affair-not all that well. We were on the edge of our seats; Creighton was like a sorcerer around a campfire telling the story of a great adventure. He was enjoying himself. Finally, at 6:10 p.m., Macdonald having resigned with his government in ruins, Creighton stopped. "That, gentlemen," said he, "is the Pacific Scandal."

We burst into applause. Most of us had never heard anything like it before; some of us have heard nothing like it since. It was a bravura performance. We knew it and he knew it. He was moved by our demonstration, though he tried not to let that show. We stood around talking admiringly after he left, then slowly dispersed to our several lodgings across the big Toronto campus through the gathering winter night.

Donald Creighton came from a literary family, the son of Laura Harvie and William Black Creighton, editor of the Methodist Christian Guardian. Born in Toronto on July IS, I902, he was brought up in a modest home on Hewitt Avenue, just east of High Park, and went to Humberside Collegiate. He then took Honour English and History at Victoria College, where he graduated in I925. He went on to Balliol College, Oxford, in the autumn of 
I 925 on a scholarship, feeling very much the colonial in accent, style, clothing, manners and money. $\mathrm{He}$ was a product of the Methodist Toronto of the I920s-a narrow and earnest society, though in its decidedly bourgeois way it tried to be civilized. In some ways it was. Its high-school education was still solid; at Humberside Collegiate Creighton had learned by heart a good deal of English poetry: Browning's "Home-Thoughts, from the Sea"- "Nobly, nobly, Cape St. Vincent to the North-West died away"-and more radically for that time, Matthew Arnold's "Dover Beach." In some ways that poem sums up Creighton's early alternations of love and despair:

... for the world, which seems

To lie before us like a land of dreams,

So various, so beautiful, so new,

Hath really neither joy, nor love, nor light,

Nor certitude, nor peace, nor help for pain;

And we are here as on a darkling plain

Swept with confused alarms of struggle and flight

Where ignorant armies clash by night.

He had an extraordinary knowledge of, and memory for, poetry. He was well-read in English literature and in French; he believed scholars should be. He was difficult to beat in that game played over drinks and friendship when one added, if one could, to the first line of a poem the next, or even the rest of the stanza.

At Oxford, Creighton read little in the constitutional history of the British Empire, often the heartland for Canadian students as the only historical ground that touched on Canada. Instead he read mainly European and British history, and slowly gathered around him, like a cloak, the great traditions of European civilization. But a Canadian he was born and it showed. Indeed, he soon came to resent not having been born and brought up English; that Humberside schooling was not Marlborough or Winchester. He would resent even more the airs and contempt reserved by the English for colonials, however talented, who might occasionally affront well-established manners and traditions.

One of those traditions was certainly that Oxford undergraduates did not marry. In London on June 23, 1926, after his first 
year, Creighton married Luella Bruce, a sprightly Canadian girl from Stouffville, Ontario. They eventually came to a decision to live for a time separately, Luella in Paris and her young husband at Balliol. Creighton wanted to do graduate work at the University of Paris when he finished his Oxford B.A. in 1927. His spoken French was not as good as his wife's; like many English Canadians he had grown up without hearing French, coming to it via French grammar. Though he was well-versed in the language and spoke it accurately, his French was heavy with English accents, his French " $u$ " and his French " $r$ " both sounding like west Toronto, which they were.

What determined Creighton's fate, however, was not his French but his lack of money. When in the autumn of 1927 he accepted a lectureship in history at the University of Toronto he did not give up ambitions of research in French history, and teaching a course in the French Revolution whettted his appetite. But on a lecturer's salary a summer's research in Paris was desperately draining, and the young couple came home from the first summer's work in I 928 in parlous financial circumstances. There was no money for a bright Canadian student who wanted to study the French Revolution in Paris and write a Ph.D. thesis on the Girondins, and who hoped to end up teaching in Britain. Creighton would have liked to live in an ample and aged English country house, surrounded by lawns, gardens, history and civilization, with Luella as Lady Creighton, and himself as Sir Donald Creighton. Instead, in his research, in his mode of living, he got Canada-primitive, grubby, thinly civilized and preoccupied with the bourgeois savagery of making money. ${ }^{2}$ Thus to Toronto he returned and in Toronto would he remain to the end of his life, save for the odd research trip abroad. He was made assistant professor in 1932 , associate in I939, and the top rank in I945.

His early years in Canadian research produced The Commercial Empire of the St. Lawrence, $1760-1850$, published in 1937. The Laurentian interpretation of Canadian history at the core of this book was derived from Harold Adams Innis. It rested on Canadian geographic reality and an economic view of Canadian history that came out of the fur trade, with its vast western and northern reaches. It was Canadian experience with a perspective out of central Canada, in which Confederation would later become the 
centrepiece. Further, the work that Creighton did for the Rowell Sirois Commission, British North America at Confederation (1939), reinforced his conviction that the strong powers given to the Dominion government in $\mathrm{I} 867$ had been systematically weakened by decisions of the Judicial Committee of the Privy Council in London. Through all this, Creighton's nationalism came gradually into being: Canadian geography made vibrant, Canadian history made articulate, and Canadian constitutional law revealed as a constant betrayal by distant British courts unknowing of Canadian ways.

So he came naturally to work on the development of Canadian nationality after I 867. After a Guggenheim fellowship in I 940-4 I and a Rockefeller in I 944-45, he settled on Sir John A. Macdonald as the focus of his research. When he applied for a Nuffield grant to enable him to go to England for the winter of $195 \mathrm{I}-52$, the research for the Macdonald biography was two-thirds complete and a good deal of Volume $\mathrm{I}$ had already been written, much of it in the ancient Canadian Archives building on Sussex Drive that now houses the War Museum. Luella wrote from Port Carling, Muskoka, on July 5, I95 I: "I hope you are roaring through chapter nine, and looking forward with happy anticipation to chapter ten and that all your [Ottawa] friends are rallying round.",3 That was all very well out in cool Muskoka, but in summer that old Archives building in Ottawa reeked of heat, and humanity in shirt sleeves.

Creighton wrote Macdonald from the documents, from Macdonald's letters and others', aiming continually to reveal Macdonald through his own words and his actions. C.M. MacInnes, a Canadian and historian then at the University of Bristol, thought that Creighton, as a result of this approach, came to be a bit hard on Joseph Howe. Creighton conceded the point:

Perhaps I was a bit hard on Joseph Howe, or perhaps, in justice to myself, I ought to say that I had not enough space to be really fair to him. I have always felt attracted to him rather than the reverse. In a biography, one must concentrate upon the central character to such an extent that the rest of the cast has to be given rather summary treatment.

There was more to it than that. Creighton was not just concentrat- 
ing on the central character, he was trying to be the central character, to see the world through Macdonald's eyes, to measure it with Macdonald's thinking. Perhaps, as H.V. Nelles has suggested, this was the result of Creighton's intense communion with the past. He liked pictures, photographs, old textures, fabrics, furniture, things that allowed him, literally in some cases, to get the feel of the past. It was as if his senses were antennae set out to bring that lost world into his mind. He would ask his students to look intently at any old photographs of their subject in order to submerge themselves in that distant ambiance. As he told Margaret Aitken of the Toronto Telegram, "one pours oneself into it." Perhaps a little too much so. Norman Ward remarked in the Saskatoon StarPhoenix that Creighton not only liked and disliked the same people as Macdonald but that he sometimes disliked Macdonald's opponents more than Macdonald did himself.

Macdonald was also more malleable than Creighton; R.C. Brown noted that Macdonald "had the master politician's sense that a conciliatory word or gesture could turn yesterday's enemy into today's ally." Would Creighton have done that? In cabinet Macdonald lived for nine years with J.A. Chapleau's unrestrained love of intrigue; when in I885 Chapleau's death was falsely reported, Macdonald praised mainly Chapleau's good qualities even to his private secretary, Joseph Pope, though he knew well what Chapleau was capable of. Creighton described Francis Hincks (vol. I, p. 2 I 7) as "bleakly clever, drably efficient," as if he enjoyed a certain vein of malice against Macdonald's opponents. Unlike Macdonald, who claimed a public man could have no resentments, Creighton seemed to have a number of them. The Hincks reference, and others to George Brown, Edward Blake, Oliver Mowat, prompted F.H. Underhill to comment in 1958 that he would have had more confidence in Macdonald as history were it not that Macdonald's political opponents "were not only intellectually deficient and morally delinquent but also physically repulsive."

Creighton delighted in resonant adjectives, rotund adverbs, piling them up: the countryside west of Kingston broadening out "comfortably in pleasant and fertile amplitudes" (vol. I, p. 9); the bedroom of Isabella in 1852 "full of equivocal silences and nervous apprehensions" (vol. I, p. 174). Such phrases call up Arthur 
Lower's comment in the United Church Observer in 1952 that "the adjective kills the noun." Still, "equivocal silences" has its own special resonance, and doubtless Creighton so intended it.

Norman Ward loved Creighton's marvellous way with the research materials of history, the way Creighton had made a glowing canvas from the primitive colours research provided. Ward quoted with delight a long passage from page 224, where Macdonald has brought his wife, Isabella, to Toronto for the legislative session. She became ill; it is January, 1856 , in a boardinghouse west on Wellington Street:

At night, when he walked homeward along King Street, the brief, sullen winter sunset had already faded in the west ... A dozen times he really expected to find her dead when he arrived ... Yet, with her feeble but persistent resolution, she lived on. She waited for him in the dim sickroom; and there, night after night, he stayed with her. The town was busy with dances, dinners, and parties ... He was inundated with invitations; but he refused them all. Night after night, while the frost struck the desolate little street into icy stillness, he sat up with Isabella; and night after night the candle burned itself slowly downward to the socket.

That's good writing. It is also sustainable history, as close to Ranke's wie es eigentlich gewesen ist ('as it really was') as one could have any reason to expect. Yet the documentary authority for it is probably thin-weather reports in the newspapers, a letter or two about Macdonald's wife's health and his life in Toronto. It illustrates Creighton's belief that history was literature, of a special kind, indeed, but grounded in the same canon, with form, plot, structure, that details would come into afterwards, the shafts of light and life that Creighton, imbued with the Zeitgeist, could evoke almost at a touch. Indeed, once the research was finished and a skeletal structure assembled, the actual writing would go quickly, page after page in Creighton's small, neat hand, with hardly an emendation. ${ }^{4}$

From the start of his work on Macdonald, Creighton was encouraged by Harold Innis, a considerable historian himself, whom Creighton much admired. The feeling was mutual. When Creighton dedicated the first volume of Macdonald to Innis, Innis 
was visibly moved. George Ferguson of the Montreal Star, visiting Innis, who was in hospital with cancer, wrote Creighton that the dedication was the finest thing Creighton had ever done. "If you had heard his [Innis's] voice and seen the charming smile and the look in his eyes ... I nearly wept." When Creighton asked Innis if he could dedicate Macdonald to him, probably neither knew that Innis was mortally ill. Discharged from hospital after treatment, Innis went home to Dunvegan Road and settled in to read the proofs of Volume I. He was highly approving. "I am of course confirmed in my earlier view that this marks a new epoch in historical writing in Canada ... and will compel a rewriting and a drastic revision of the content of Canadian history. What a contrast with Mackenzie King!" Innis told Ferguson that "it would set a mark so high that it might scare MacGregor Dawson off the task he had undertaken [the biography of King]!" His only complaint to Creighton was that each chapter read all too quickly. As for Creighton's dedication of Macdonald to him, Innis said it was "the highest honour, academic or otherwise which I will ever achieve ..."

If the highest, it was also the last. Innis hoped "to get back to normal in the not too distant future but it is exasperatingly slow. I still write letters only to the Creightons ..." That was in August, 1952. Innis died on November 8. As the news of Innis's cancer circulated among his friends, Gerald Graham, Rhodes Professor of Imperial History, wrote to Creighton: "I can hardly bear the thought of getting along without him ... I shall never have another friend like him, and it's going to be a bloody lonely world." Graham, Creighton loved Innis. Innis was his intellectual mentor, and Creighton was Innis's interpreter. One had difficulty with Innis's gnarled and abstruse prose; Creighton made its themes manifest in The Commercial Empire of the St. Laurence (1937), Dominion of the North (1944) and Macdonald. Creighton remembered Innis in a biography published in 1957 . He also felt that this biography, like some of his other books, had never had its proper due.

That was Creighton's besetting sin. Envy unnerved his spirit, clouded his thought, made a Dover Beach of his joy. Ultimately Creighton would receive all the accolades Canada and friends could offer, including the Order of Canada; but in the important 
world of Britain, who knew or cared much about Canada, dead Canadian politicians, or even live Canadian historians? Or about the fact that Max Beloff in the Spectator declared in 1953 that in "Donald Creighton the University of Toronto has one of the half dozen best historians now writing anywhere in the English-speaking world"? When Creighton went to England he was warmly greeted by his friends, but otherwise the great society of London paid little attention to one of the six best historians writing in the English-speaking world. Macmillan of London took only 250 copies of his Macdonald. It was gall and wormwood.

That may have been one reason why by the 1960 s Creighton had come to dislike the English, their ways, their sublime indifference to things Canadian. He believed in the Crown and the Commonwealth, but now he often found the English intolerable. Of anglophile Canadians like Vincent Massey he was contemptuous. What created this change was a combination of things, not least his Canadian nationalism, but also the difference between the young impressionable Creighton of the mid-I920s and the mature historian of the mid-1960s, made bitter by accomplishment insufficiently recognized.

Cyril James, Principal of McGill University from 1939 to 1962 , asked by the Rockefeller Foundation to supervise the work going forward on the Mackenzie King biography, asked Creighton about his mode of operation. There was resentment in Creighton's reply. While he had had some grants-in I944-45 a Rockefeller, in I 95 I-52 a Nuffield, and a few short summer grants from the University of Toronto- "no other body and no other person has supported my project either directly or indirectly. I have done all the work myself, and have never had any secretarial assistance. I must confess that I have often envied the lavish fashion in which $\mathrm{Mr}$. King's biography has been supported."

Creighton's other deadly sin was anger. He had a short temper that could be aroused by ignorance and by offences against history or his vanity. He was a member of the Historic Sites and Monuments Board of Canada from I 957 to I 97 I; once at Niagara-onthe-Lake in the late 1960 s he was accidentally left behind at the hotel, while his colleagues went off surveying Fort George. Someone remembered him and went back. There he was, all 6 foot, 2 
inches of him, pacing up and down the sidewalk outside the Oban Inn. He was in a smoking fury. As he got in the car he gave one contemptuous snort, "You sons of bitches!" In half an hour it had all passed.

Creighton's reputed insensitivity was apt to be his own astringent mixture of those two sins, envy and anger. He was not a boor, even if occasionally he could behave like one. He could be extraordinarily perceptive. In a conversation with Historic Sites colleagues once, the talk had come around to the tenderness and delicacy of women. Someone said, "It's not exactly like that, is it? Women are creatures of blood and earth. In many ways they are tougher than men. Delicacy is a cover for their elemental nature." Creighton looked up, his eyes wide and shining. "A wonderful remark," he said.

He was sympathetic and generous to his graduate students and that usually comprehended wives, children and income. When one graduate student and his wife both had to set to and teach Basic English at night school to make ends meet, Creighton was horrified. "Oh, God, so it's come to this!" He sought out Vincent Bladen and between them they found $\$ I, 200$ to establish the student as an Innis Memorial Scholar. "There," he said, "now you can find your way more comfortably in the wake of a great Canadian scholar."

John A. Macdonald: The Young Politician was published by Macmillan of Canada in mid-October, 1952. John Gray, the company president from 1946 to 1978 , took an active interest from the start. Macmillan printed frve thousand copies, a big printing. It was exhausted in six months, and at least two further printings were needed. Macmillan was probably made bold by the current success of Bruce Hutchison's book on Mackenzie King, which sold fifteen thousand copies in its first year. The Incredible Canadian was part reminiscence, part history-in some ways a terrible book, but vivid it was. The vividness found in Lytton Strachey and others prompted Grattan O'Leary to note that new techniques in biography "added a new terror to death." Creighton could quote chunks from Lytton Strachey and would chuckle "like a schoolboy at Strachey's subtlety and wickedness.' 
Creighton's book was received with tremendous acclaim. It was the first substantial Canadian biography published in many years, really since O.D. Skelton's Laurier of $192 \mathrm{I}$. Gratton O'Leary in the Ottawa Journal said it was the best since Willison's Laurier of I 905 . There were a few caveats from Arthur Ford of the London Free Press, and the Peterborough Examiner did not like the opening sentence; but really there was an explosion of enthusiasm. Macdonald's granddaughter, Isabella Macdonald Gainsford, whom Sir John used to call "Puss," liked it. Arthur Meighen was delighted, although he could not agree with Creighton's implied criticism of the Double Shuffle of I 858 . (The Cartier-Macdonald government, said Meighen, "complied strictly with the law" and with its spirit.) C.M. MacInnes wrote Creighton the minute he finished the last page with his "very great admiration ... The function of the historian is to tell a story ... there are still some left who believe that history should also be literature." ${ }^{9}$

Creighton was in Ottawa in October, 1952, for the launching of Volume I, and, fresh from the accolades above, returned to England for the research and writing of Volume 2, this time on a Rockefeller grant. The Canadian research was already in hand, but he needed to work in English collections. While in England he was solicited to stand for the presidency of the University of New Brunswick. That was almost certainly Beaverbrook's doing. Creighton was annoyed with the University of Toronto for the lack of recognition for his three substantial works already published, and his Macdonald just launched. One of the last things Innis did, in the summer of 1952, was to tell Claude Bissell, the new vice-president of Toronto, that they could very well lose Creighton, and that Creighton's complaints to Sidney Smith were justified. Bissell acted, Smith accepted, and by mid-September, I 952, Creighton was appointed chairman of Division I of Graduate Studies for three years, in recognition of his "outstanding contribution to the University." He would be paid an extra $\$ 500$ a year, bringing his salary to $\$ 8,100$. That did not prevent him from being interested in the presidency of U.N.B. In the event, Colin B. McKay was appointed and Creighton's aspirations as university president seem to have gone no further.

He stayed in England writing until the last minute, arriving in 
Toronto just before the start of lectures, in late September I953. He was on the second-last chapter, but he was now plunged into academic responsibilities. He was hoping to finish by the summer of I954. Macmillan did not push him. We'll welcome your manuscript when it comes, John Gray said, and added, "I expect to print I s, , oo (count 'em)."

Gray was reading chapters as Creighton sent them, and by December, 1954, he had read the first eleven and had a few comments. The Red River Rebellion of I 869-70 was unclear, especially its outcome. That was not surprising, for it was a difficult story to make clear. Moreover, though Gray professed this a minor point,

the impression that comes through of your own complete lack of sympathy toward the half-breeds. This may be entirely designed, but if not you should be aware of it. The feeling is conveyed in your choice of adjectives (at the time of the 1870 rebellion and again in ' 84 ) intractable, improvident, restless, unpredictable and the very fact that they are almost always referred to as half-breeds instead of metis. The adjectives are, of course, accurate but I feel sure you have more sympathy for them than the reader would think. As it stands this impression would give much offence in the West.

Gray knew the West. All through the I930s he had canvassed it by train two or three times a year from Winnipeg to Vancouver, weeks at a time, selling Macmillan's books to provincial Departments of Education. It is difficult to know what changes Gray's comments effected. It was Creighton's business, and Gray thoroughly admired the manuscript. "I am congratulating us," he said; "We are going to be very proud of this book." Nevertheless, Creighton was Ontario-born just seventeen years after the Saskatchewan rebellion, and did not really know the West. The point is not irrelevant. It's a long way by train (or any other way) from Toronto to Winnipeg. Macdonald wrote Cartier, November 27, I 869, sympathizing with the position of the Métis. Creighton quoted the letter (vol. 2, pp. 46-47): "All these poor people know is that Canada has bought the country from the Hudson's Bay Company, and that they are handed over like a flock of sheep to 
us ..." But Creighton omitted what some might have considered the most important part of that letter. It goes on: "and they are told that they may lose their lands and everything they value. Under these circumstances it is not to be wondered at that they should be dissatisfied, and show their discontent." It is impossible to say whether Creighton deliberately suppressed this second section. The quotation was already sufficiently long, and Creighton did not like long quotations. They cluttered narrative. Gray could not have known what this omission was, but Creighton's suppression of it, if that is what it was, may have been an illustration of what was nagging at the back of Gray's mind."

If Volume I created delight, Volume 2 created sensation. Creighton opened up a good deal; invigorated, emboldened by the success of Volume I, he shook himself free of any lingering academic hesitations and launched himself into the Macdonald of the post-I 867 years. His boldness was in effect sanctified by the tremendous increase in the range and quality of the Macdonald Papers from 1867 to 1891 and by his access to Lady Macdonald's diary. That made up for the woeful lack of domestic correspondence between Macdonald and Agnes, for the disappearance of which she had been mainly responsible. Agnes outlived her husband by thirty years (she died in I 921 ) and she had ample time to destroy correspondence, both her letters in her husband's papers, and his letters in hers.

Volume 2 brought out the superlatives, in Arthur Meighen not least: "This is the finest biography any Canadian has produced. We must never forget the years of toil, the dauntless perseverance which these volumes have cost you. I comfort myself in the thought that my children and my children's children will feel the same inspiration that I have felt." George Stanley in the Queen's Quarterly agreed. It was the combination of scholarship and literary skill, "too rarely found in historians, that gives Mr. Creighton's work the quality of greatness." Stanley disagreed with Creighton's interpretation of Louis Riel and with Creighton's views of Macdonald's French-Canadian colleagues, but all that was forgiven in a book that "blazes with spirit ... It fulfils the hardest task of the historian, that of breathing life into the past. Macdonald stands before us warm, humorous, clever, lovable." 
Hilda Neatby entered, however, a discerning critique on the CBC's "Critically Speaking." We don't get into Macdonald's mind, she said,

and for a curious reason. Professor Creighton is constantly opening the door, but having done so he stands in the way and blocks the view. And we hear a voice, but we are not quite sure whether it is Macdonald or Creighton who speaks. Is it, for example, Macdonald or his biographer who defends the gerrymander of 1885 as essential for the winning of the election? This method, used throughout the book, of blending his voice with the voice of his subject, prevents $\mathrm{Mr}$. Creighton from offering the mature and informed judgments on Macdonald that he is so abundantly qualified to make.

The first volume of Macdonald took the Governor General's gold medal for literature in I952, and Volume 2 took it in I955. Macdonald came out in paperback. But within twenty years much had changed. Political history, and political biography, had become less fashionable; the younger spirits of the historical academy had shifted their interest to social history. Fashion is apt to be heedless as well as ruthless. By the I 960 s Creighton's personal glory had come to be clouded by new ideas and movements that buffeted his sensibilities. He had never held back from expressing his opinions on public questions; he could put his marvellous turn for language to polemical uses, and that had begun very early. Public affairs, public policy, mattered; the anguish of his last ten years came from his profound knowledge of Canadian history, especially of Confederation, and from its juxtaposition with Canada's present, of the Quiet Revolution and the indignity of the FLQ crisis in 1970.

Creighton had always had an appreciation of French-Canadian scholarship. He admired Georges-Henri Lévesque, Dean of Social Sciences at Laval, and he had rewarding relations with Michel Brunet of the Université de Montréal. He helped to bring Brunet to Toronto as the Gray Lecturer in 1958. In 1959 he had to decline chairing a Canadian Historical Association meeting at which Brunet would speak, not because of Brunet, but because he, Creighton, was not sufficiently bilingual.

What eventually alienated Creighton was French-Canadian 
nationalism. It made him angry. In May of I971 he told Eugene Forsey that French-Canadian nationalism had "succeeded in weakening my nation." Donald Wright, in a comprehensive and able analysis of Creighton's attitudes to French Canada, makes the point that Creighton's anger too often was taken for intolerance. Creighton was rather, Wright argues,

defending the truth as he understood it ... While he could tolerate differences of interpretation, he could not abide what he saw as outright fabrication ... Two nations, associate state, special status: these were all notions Creighton found big-hearted, soft-headed, rooted in bad history and ultimately dangerous to his country. On this point he was not alone.

But by the mid-1970s he was largely beyond those positions, which at least had historical justification. At times he could be venomous, even paranoid about French Canadians, their hands "in the till" as he put it. It warped his judgment, inflamed his mind; Mirabel airport sent him down "deep ... in the caverns of his rage.",14

Creighton's alienation by French-Canadian attitudes came also because he viewed Quebec nationalism from premises that were old and even then not always at one with French-Canadian realities. Had he understood the ambiguity in Louis Fréchette's poem of the I 880s, "Le Drapeau Anglais"? A young boy and his father are in Montreal and the boy notices the Union Jack flying at the top of a building. His father explains that it's a fine flag, it has made his country prosperous and has given him political freedom. Then the boy asks,

-Mais, père, pardonnez si j'ose ...

N'en est-il pas un autre, à nous?

-Ah, celui-là, c'est autre chose,

Il faut le baiser à genoux!

That other flag represented French Canada's attachment to France and to French. The British flag also represented the conquest, however generous British rule had, mostly, been. Brunet reminded Creighton in August, I 956, "Survivre n'est pas vivre." ${ }^{, 15}$ Creighton 
seemed not to understand, either, the French-Canadian sense of being continually threatened, surrounded as it really was now, by a tide of English growing incrementally. The new television programs of the 1960s, so many of them in English from both Canada and the United States, made the threat to the French language all the more palpable.

Towards the end of the I970s, when Creighton was already ill with cancer, some friends took him to a performance of Richard Strauss's Der Rosenkavalier, an opera that Creighton knew only distantly. Towards the end of the first act the Marschallin, the Princess von Werdenberg, in her mid-thirties, embraces her seventeenyear-old lover Octavian, first with love, then with philosophy. You will love and marry someone else, she says, someone younger and prettier than me. Time runs off with us all. You can't hold it.

Time flows on, silently, like sand in an hour-glass.

Oh, Quinquin! Very often I hear it running-inexorably.

It was not the first time such reflections had come to Creighton. He himself used to say, "all, all is ashes." It is evoked magically in the splendid third act of Rosenkavalier when the Marschallin, with Viennese elegance and restraint, ushers Octavian out of her life and gives him to a younger woman. Creighton was in tears.

Cancer caught him finally, on December I9, I 979.

A few months later, in the September, 1980, issue of the Canadian Forum, H.V. Nelles published "Creighton's Seminar," a vivid portrait of Creighton the professor. "He taught us first and foremost to respect our evidence. We were expected to plunge into the documents at an early stage and face the bewildering past directly ... to exhaust all of the readily available primary sources for our papers." It is a measure of Creighton's integrity as professor and scholar that what had been true in 1950-5I was still true two decades later.

Creighton had a scholar's passion for accuracy and a dramatist's urge to tell a good story. There may have been other historians who took their page proofs to the archives to check the quota- 
tions; I don't know of any but Creighton who did. He might well have resented one's saying that Macdonald was his greatest work, but in the perspective of his whole career, it is. Of course there are things wrong with it. Not a few of the critics were at least partly correct: Underhill's spite had some reason in it; Hilda Neatby came as close as anyone to being right, but even she was an admirer, even with her reservations. Sometimes one has to reckon with touches of apparent verisimilitude that are Creighton's sense of drama grounded on a careful reading of the sources and of newspaper weather reports. Anyone who has tried knows how difficult it is to do what Creighton did with Macdonald. The men and women he described, all, all, are dead; their parties, their talk, have disappeared almost, but not quite, without a trace. The traces they left in the archives and in the old newspapers were enough to allow Creighton to make a vivid history of Macdonald's life.

Creighton's work is inimitable: for its grace, its sheer power of evocation, driven by Creighton's passion for making the past alive and breathing. History happened; Creighton never forgot that elementary lesson. Whatever he touched in those two volumes seemed to want to shake off accumulated dust, stand to its feet, and move. Though dead, Macdonald speaks; his jokes and stories are still with us. Creighton died in I 979; his Macdonald lives on.

\section{NOTES}

I This recollection is obviously personal, but it has been read, along with the rest of this introduction, by Alan Wilson, a fellow Ph.D. student in the seminar, recently retired as Professor of History, Trent University. He was a graduate student of Creighton's in the I950s, and his recollections and comments have added much to this account. Viv Nelles of York University raised fascinating (and profound) questions, some that came from his encounter with Cynthia Creighton Flood's story cited immediately below. (Viv Nelles to P.B.W., I 3 June, 23 October, 1997.) Michael Cross, a younger colleague of Creighton's at Toronto, now at Dalhousie, offered perceptive comments on this introduction and on the later Creighton. To all three my gratitude; I hope I have translated their suggestions not too imperfectly.

2 Derived from what is perhaps the most challenging work on Creighton, by his daughter, Cynthia Creighton Flood, "My Father Took a Cake to France," in Malahat Review, 87 (Summer, I989), especially pp. I I4-I 5, I I8-19, I 23. 
3 National Archives of Canada (NA), D.G. Creighton Papers, MG 3 I D77, vol. 2, Luella to D.G. Creighton (hereafter DGC), 5 July, I95 I. I am grateful for the discernment and kindness of Robert Fisher of the Manuscript Division of the Archives for making available to me during half a week's visit to Ottawa a selected group of the Creighton Papers.

4 Ibid., C.M. MacInnes to DGC, I September, 1953; ibid., vol. I6, DGC to MacInnes, 23 October, 1953; Toronto Telegram, 23 February, 1956, reported by Margaret Aitken; R.C. Brown, "The Historian as Biographer," Canadian Forum, vol. LX, no. 702 (September, 1980), p. I0; Norman Ward in the Saskatoon Star-Phoenix, November, 1952, in DGC Papers, vol. I7; the Underhill remark is quoted by Carl Berger, The Writing of Canadian History: Aspects of English-Canadian Historical Writing, 1900-1970 (Toronto, 1976), p. 225 .

Ramsay Derry comments on Creighton's methods and style of writing in the introduction to Donald Creighton, The Passionate Observer: Selected Writings (Toronto, 1980), p. ix. Viv Nelles notes Creighton's view of history as literature, Nelles to PBW, 23 October, 1997.

5 DGC Papers, vol. 2, G.V. Ferguson to DGC, I4 May, 1952; Innis to DGC, Is July, 1952, from 92 Dunvegan Road; vol. 28, Innis to DGC, 2 August, I952, addressed to I 8 Rawlinson Road, Oxford, where Creighton and his wife were staying while Creighton was writing Volume 2.

6 DGC Papers, vol. 2, Graham to DGC, 29 April, 1952, from Princeton.

7 The Spectator (London), 6 March, 1953; DGC Papers, vol. 2, DGC to Cyril James, 9 January, 1953.

The Historical Sites and Monuments Board recollections of Creighton are mine. The graduate student and his wife whom Creighton helped were Alan and Budge Wilson. (Alan Wilson to PBW, 26 June, I997.)

8 Cited by Grattan O'Leary in his review of Macdonald, Ottawa Journal, 25 October, I952; Alan Wilson to PBW, 26 June, 1997.

9 For a history of Canadian biography, see Carl Berger, The Writing of Canadian History, especially chapter 9, "Donald Creighton and the Artistry of History," pp. 208-37. Arthur Ford's review is in London Free Press, 25 October, 1952, the Peterborough Examiner's, I 2 November, 1952. For Mrs. Isabella Macdonald Gainsford's letter, see DGC Papers, vol. 6, is February, 1953; Arthur Meighen's is in ibid., I December, 1952; for C.M. MacInnes, see ibid., vol. 2, I September, 1953 .

Io Ibid., vol. 2, DGC to B.F. Macaulay, 27 June, I953, from Oxford; Macaulay to DGC, 18 September, I953, personal and confidential, from Fredericton.

Creighton's annoyances with University of Toronto were various, some of them with the chief accountant. Harold Innis intervened about what he considered the university's shabby treatment of Creighton; see ibid., vol. 28, Innis to DGC, 2 August, 1952; ibid., Sidney Smith to DGC, 17 September, 1952. Creighton after his stint as chairman of Division I, Graduate Studies, was appointed Acting Chairman of the Department of History as of I January, 
I955 (replacing Ralph Flenley) and chairman as of I July, 1955, which post he held until 1959 .

I I Ibid., vol. 2, DGC to W.L. Morton, I 8 November, I953; Gray to DGC, 3 September, I953.

I 2 Ibid, vol. I6, Gray to DGC, I7 December, I954. For John Gray's life, see his Fun Tomorrow: Learning to Be a Publisher and Much Else (Toronto, 1978), pp. $179,182-83$. It is sad to record that this marvellous man died four months after writing the preface to his book.

Macdonald's letter to Cartier is in vol. 5 i 6 of the Macdonald Papers, in the letterbooks, which are quite complete for this period. The original letter Cartier sent on to Hector Langevin; thus it was not destroyed with Cartier's papers, and is in ANQ, Langevin Papers, boite 18.

I 3 DGC Papers, vol. 6, Arthur Meighen to DGC, 7 October, I955; G.F.G. Stanley's review in Queen's Quatterly (1955), pp. 592-94, also in DGC Papers, vol. x6; Hilda Neatby, "Critically Speaking," 9 October, I955, typescript in ibid.

14 Ibid., vol. 26, DGC to Eugene Forsey, 9 May, 197 I, quoted in Donald A. Wright, "Donald Creighton and the French Fact, 1920s-1970s," in Journal of the Canadian Historical Association, vol. 6 (1955), p. 259; ibid., p. 266.

Creighton's paranoia in his late years is noted by Michael Cross, a former colleague, Cross to PBW, I6 July, I997, and especially by Creighton's daughter. See Cynthia Flood, "My Father Took a Cake to France," p. I 2 I.

Is DGC Papers, vol. 3, Brunet to DGC, I I August, 1956, cited in Wright, "Donald Creighton," p. 254 -

I6 For Creighton's remark, "All, all is ashes," see Cynthia Flood, "My Father Took a Cake to France," p. II S. The recollection of Creighton at Der Rosenkavalier is Ramsay Derry's. See his introduction to Creighton's The Passionate Observer, pp. vii-viii.

17 H.V. Nelles, "Creighton's Seminar," Canadian Forum, vol. LX, no. 702 (September, I980), p. 6.

\section{BIBLIOGRAPHICAL NOTE}

There is no book about Donald Creighton but there are many articles and other shorter works. The most important is by his daughter, Cynthia Creighton Flood, "My Father Took a Cake to France," in the Malahat Review, vol. 87 (Summer, I989), pp. I I 9-24. The Canadian Forum (September, 1980) has a Creighton symposium with five articles, the most perceptive of which is Viv Nelles's "Creighton's Seminar," pp. $5-6$. Also valuable is R.C. Brown's "The Historian as Biographer," pp. 9-10. A recent, comprehensive and well-made academic piece is Donald A. Wright, "Donald Creighton and the French Fact, I920s-1970s," in 
Journal of the Canadian Historical Association, New Series, vol. 6 (1995), pp. 24372. Readers will find in Wright's footnotes a cornucopia of articles on Creighton's career. Carl Berger has a fine chapter on Creighton in his The Writing of Canadian History: Aspects of English-Canadian Historical Writing, 1900 to 1970 (Toronto, 1976), "Donald Creighton and the Artistry of History," pp. 208-37. A Festschrift for Creighton was published by Macmillan in 1970: John S. Moir, ed., Character and Circurnstance: Essays in Honour of Donald Grant Creighton. This book includes Moir, "Donald Grant Creighton," pp. I-8, and J.M.S. Careless, "Donald Creighton and Canadian History: Some Reflections," pp. 8-22. Ramsay Derry provides a handsome introduction about Creighton in the collection The Passionate Observer: Selected Writings by Donald Creighton (Toronto, 1980). My obituary of Creighton is published in the Royal Society of Canada, Proceedings, vol. XVIII (I980), pp. $73-77$, some bits of which have surfaced in this introduction. 


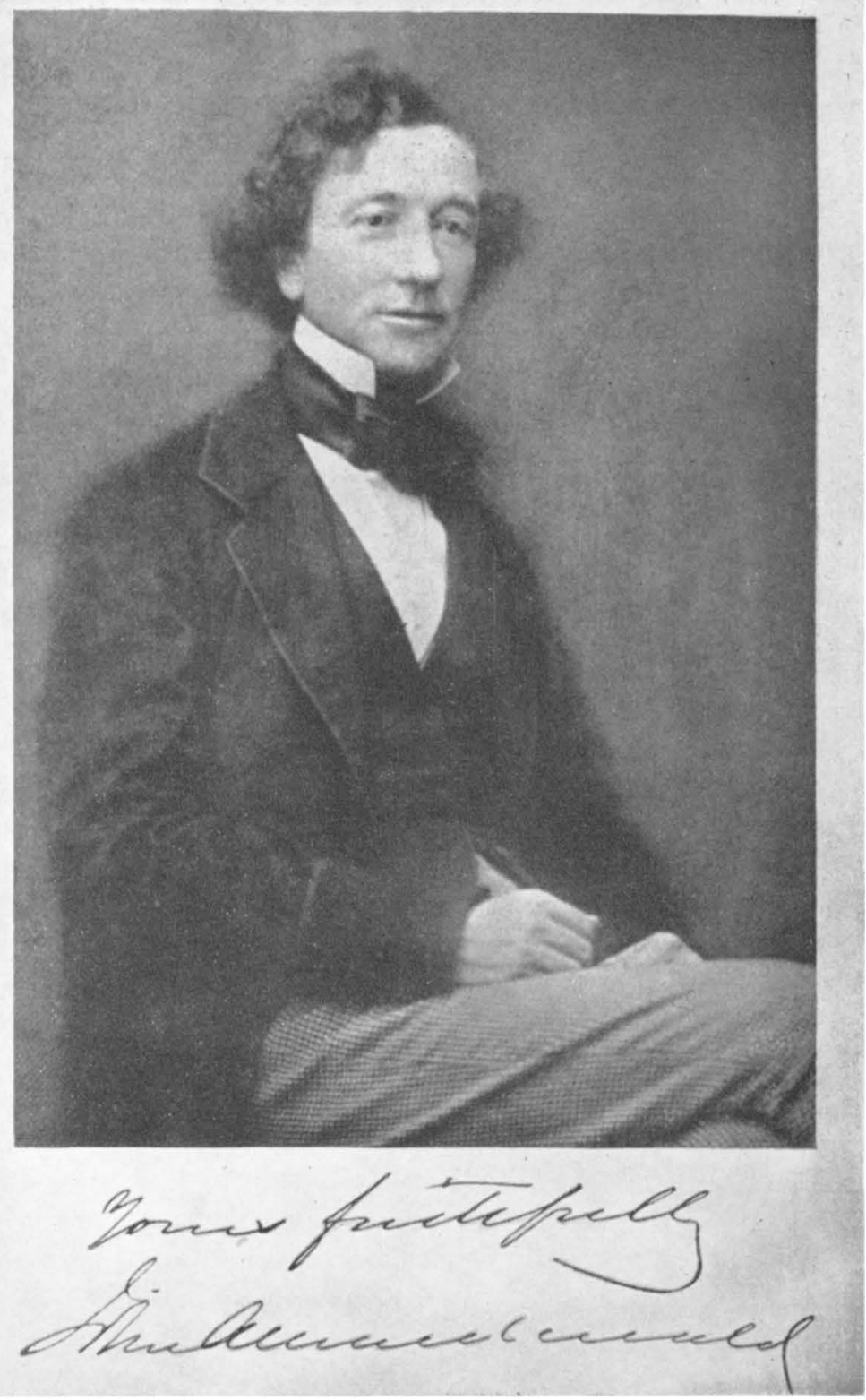

JOHN A. MACDONALD, 1842 


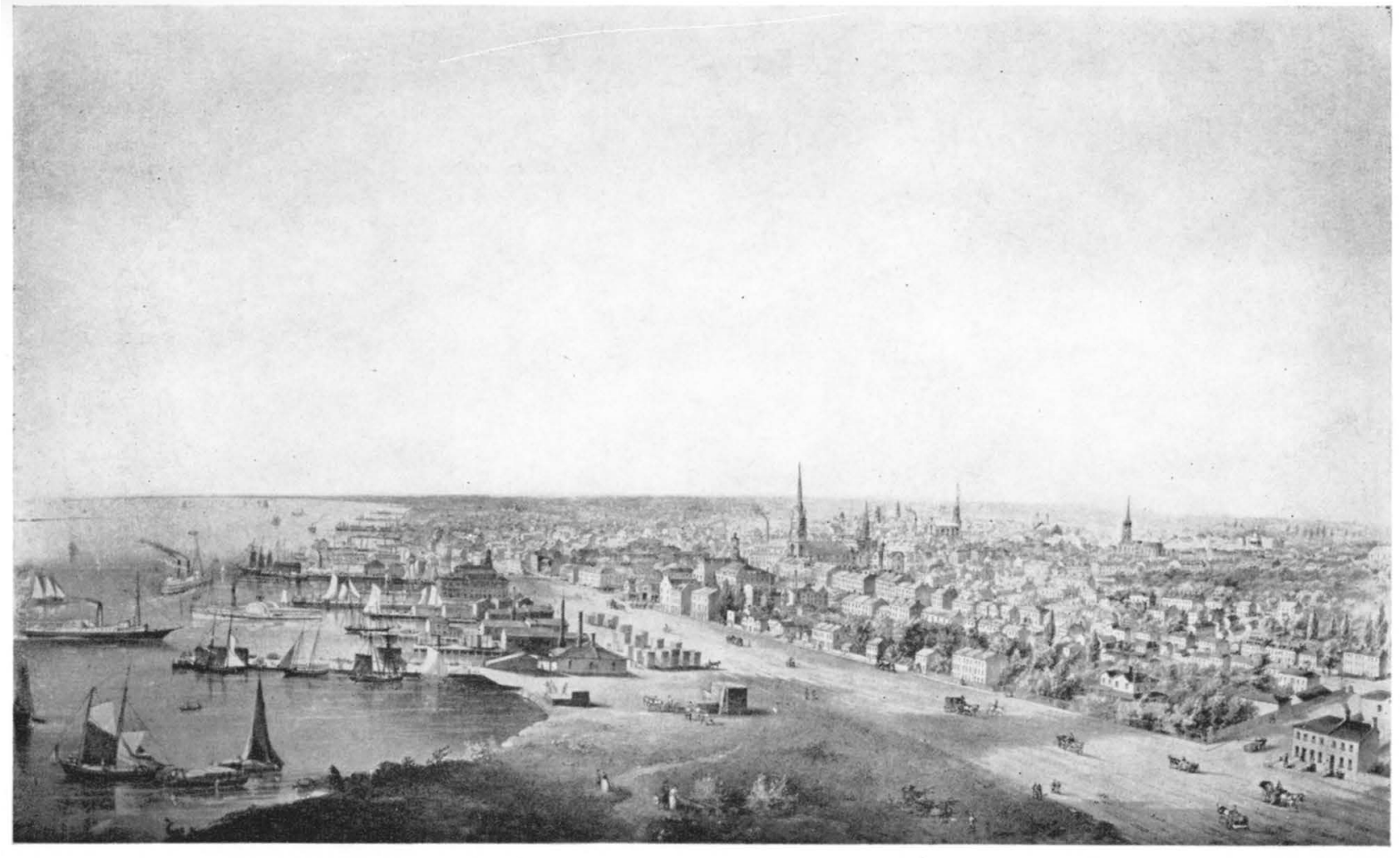

TORONTO IN THE FIFTIES 


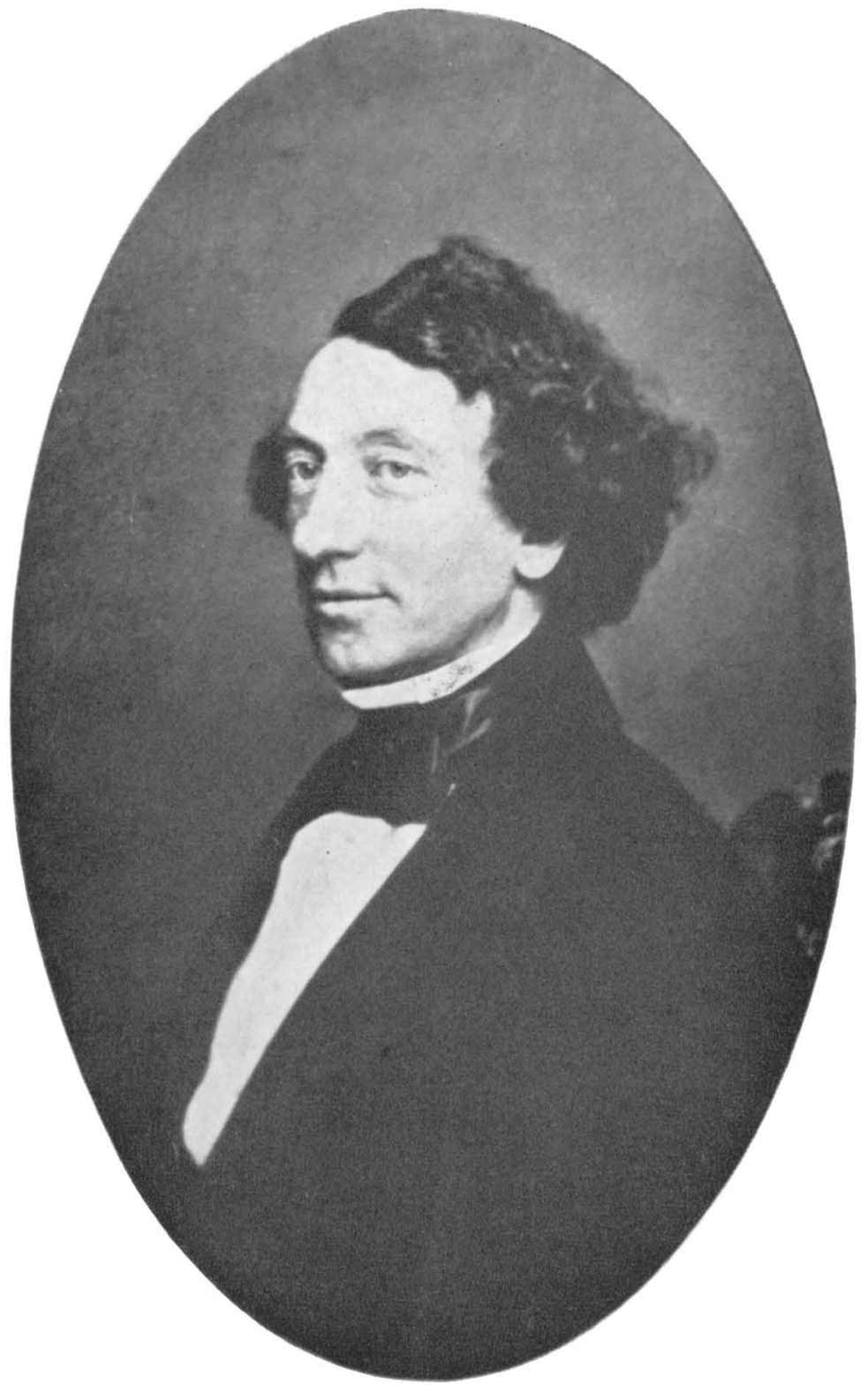

JOHN A. MACDONALD, ABOUT 1856

Public Archives 


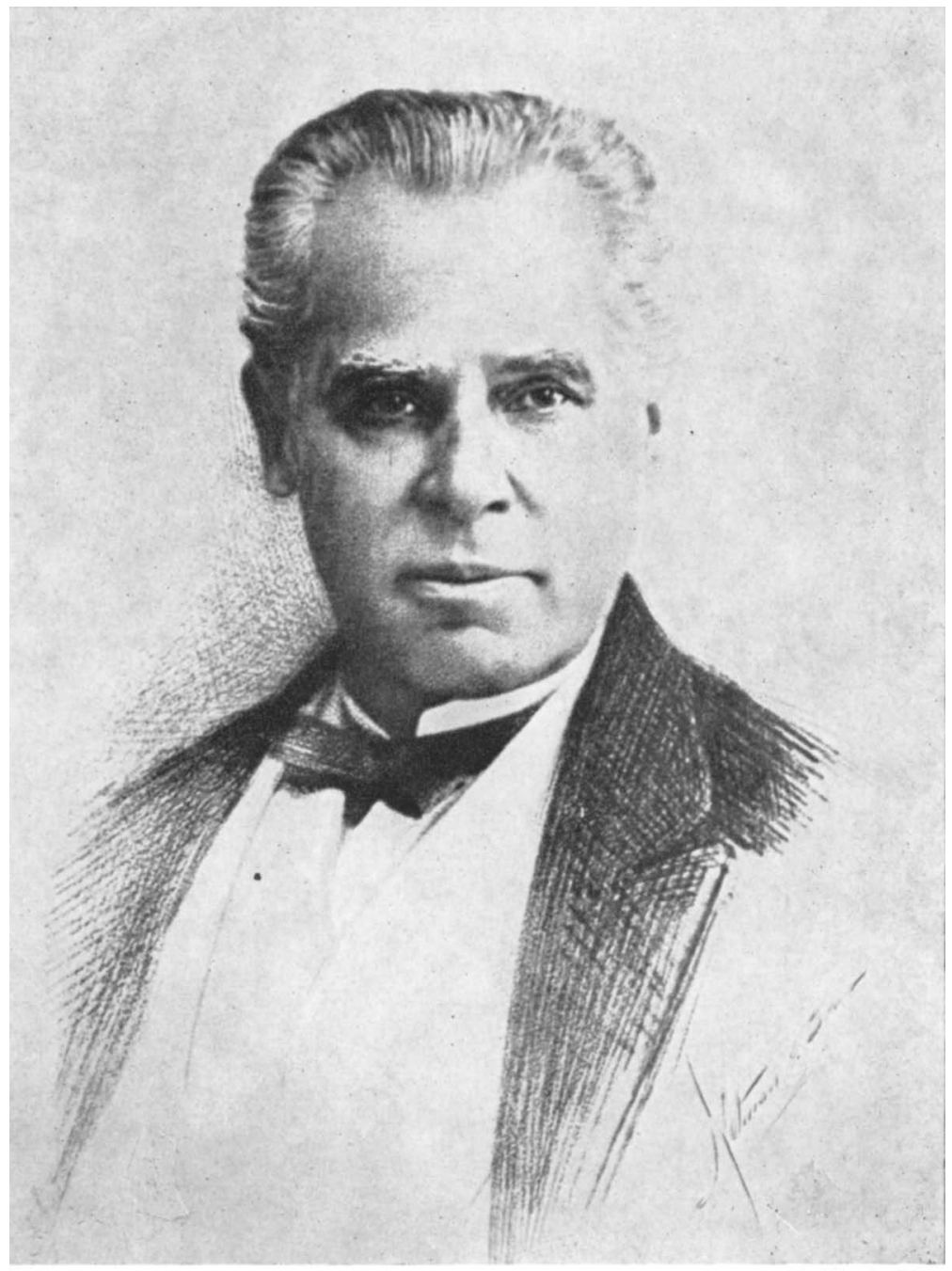

Public Archives

GEORGE ETIENNE CARTIER 


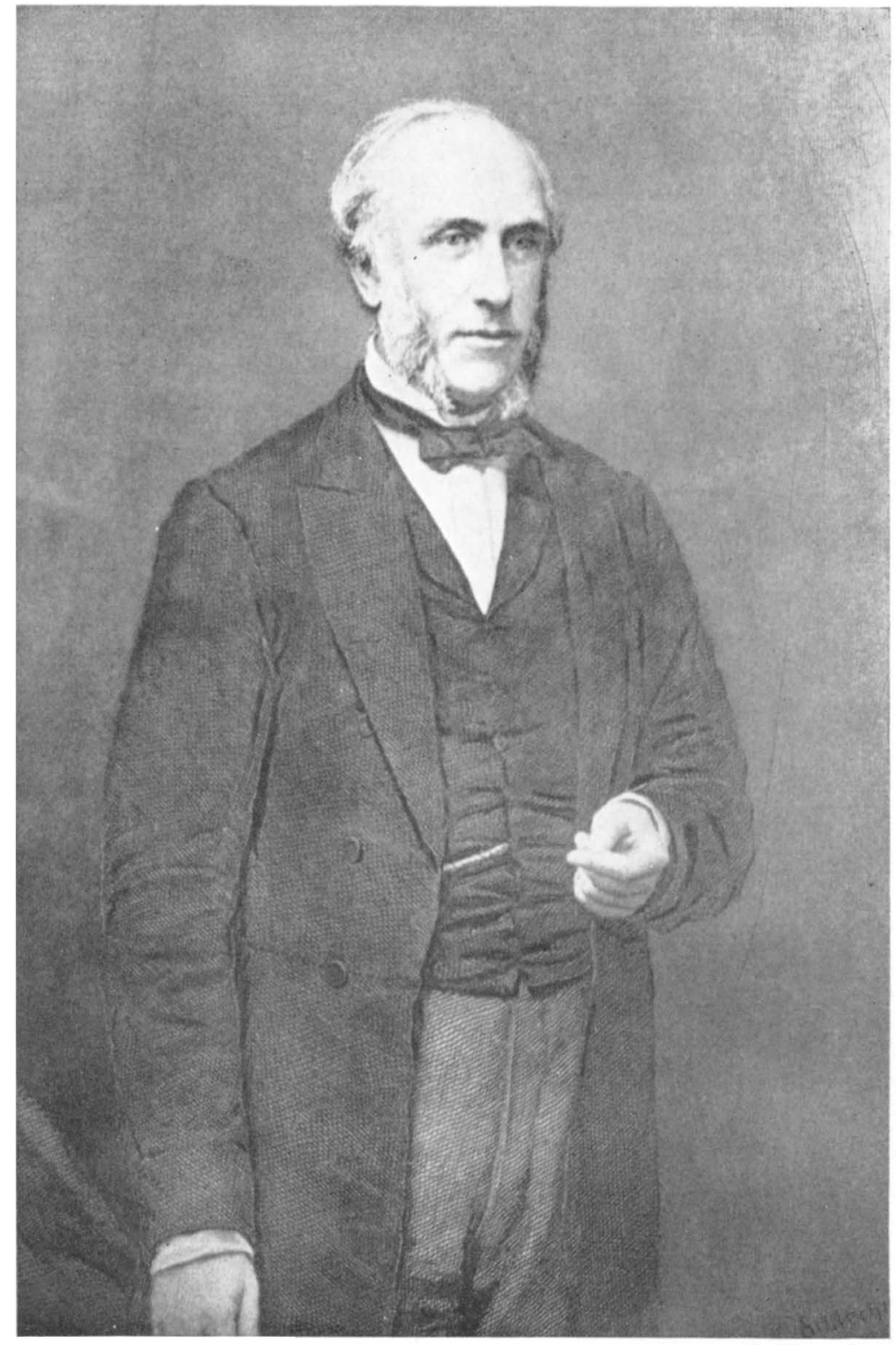

Public Archives

GEORGE BROWN 


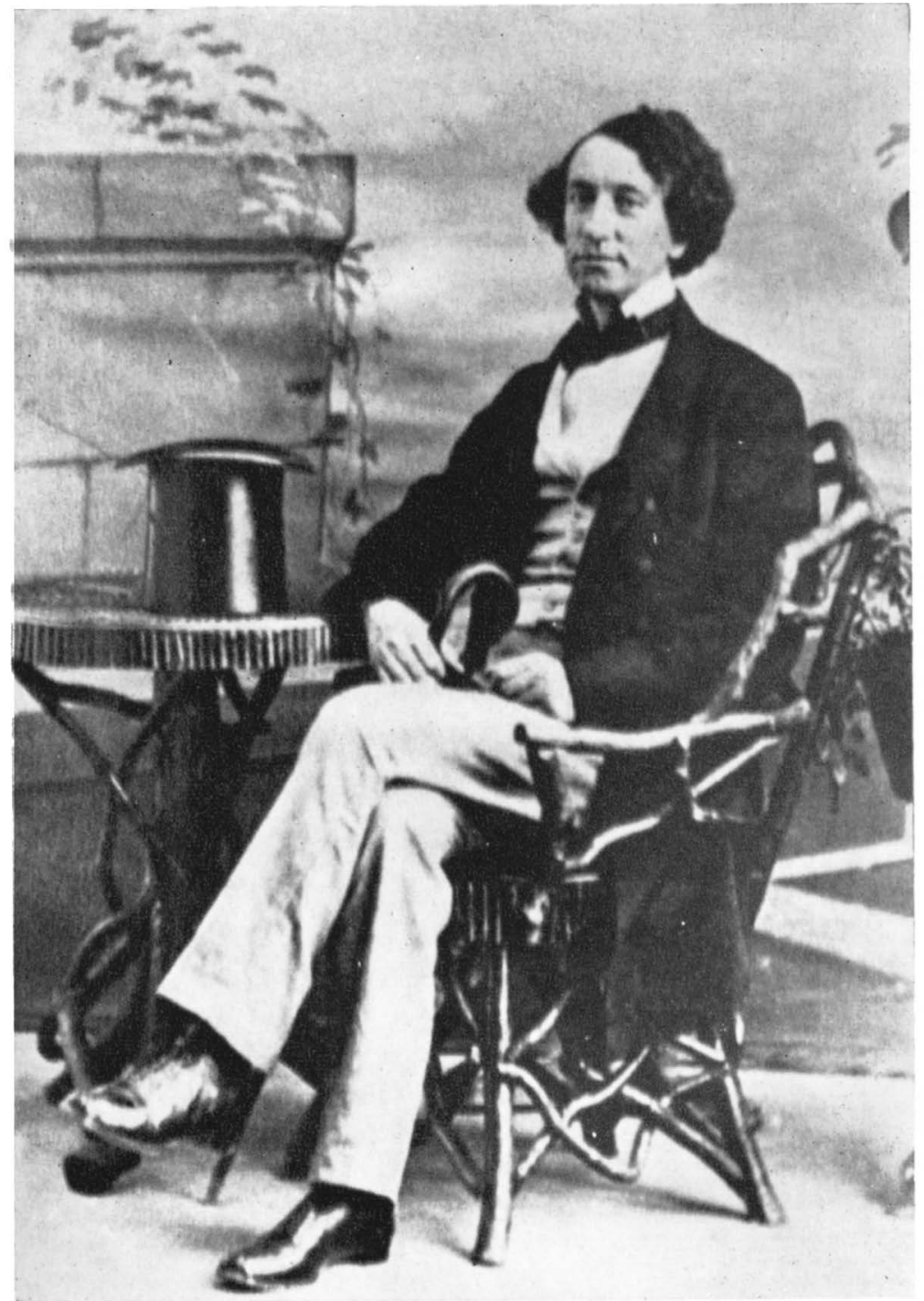

Public Archives

JOHN A. MACDONALD, 1861 


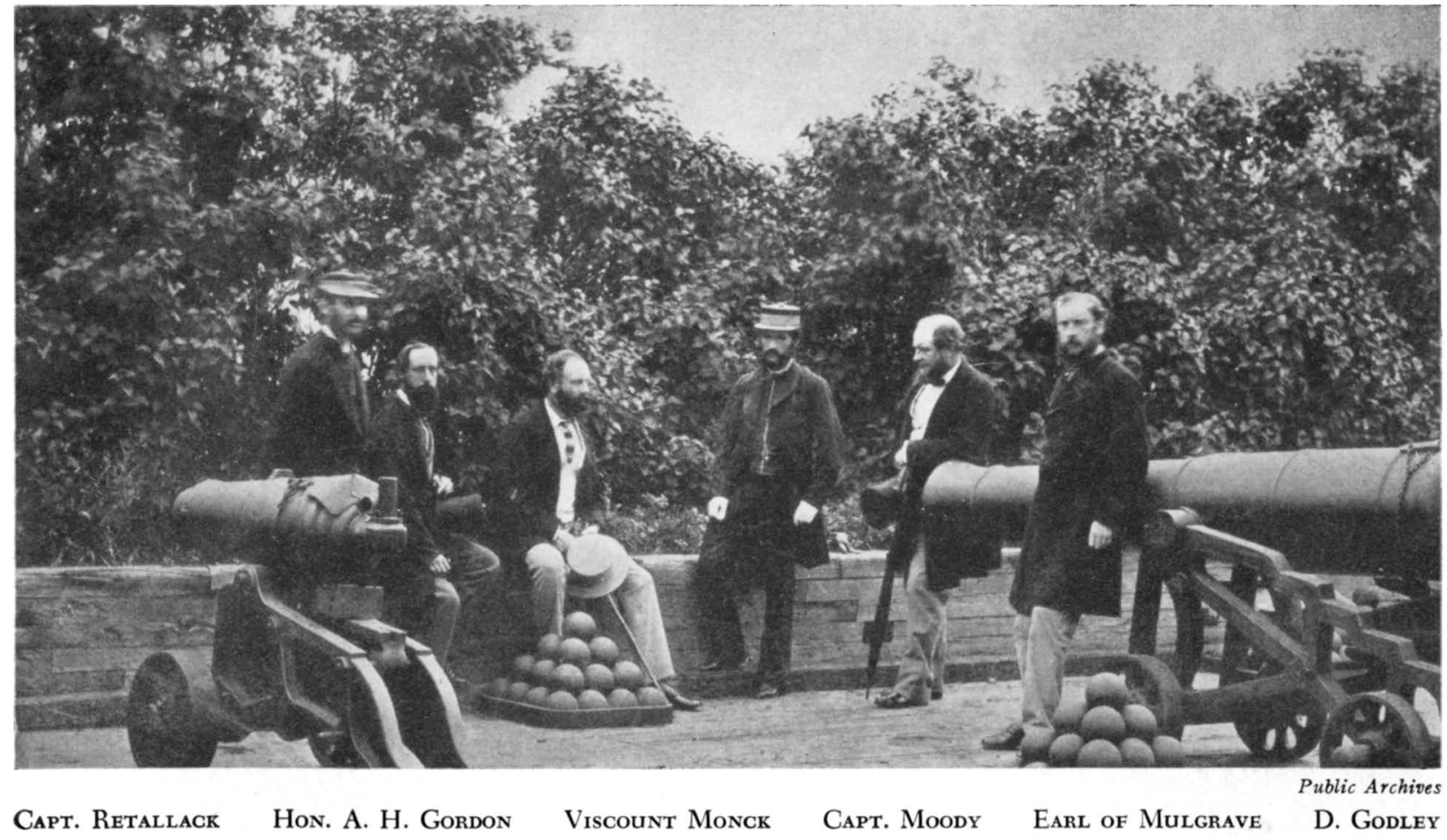

GOVERNORS OF BRITISH NORTH AMERICA AND STAFF, QUEBEC, AUGUST, 1862 


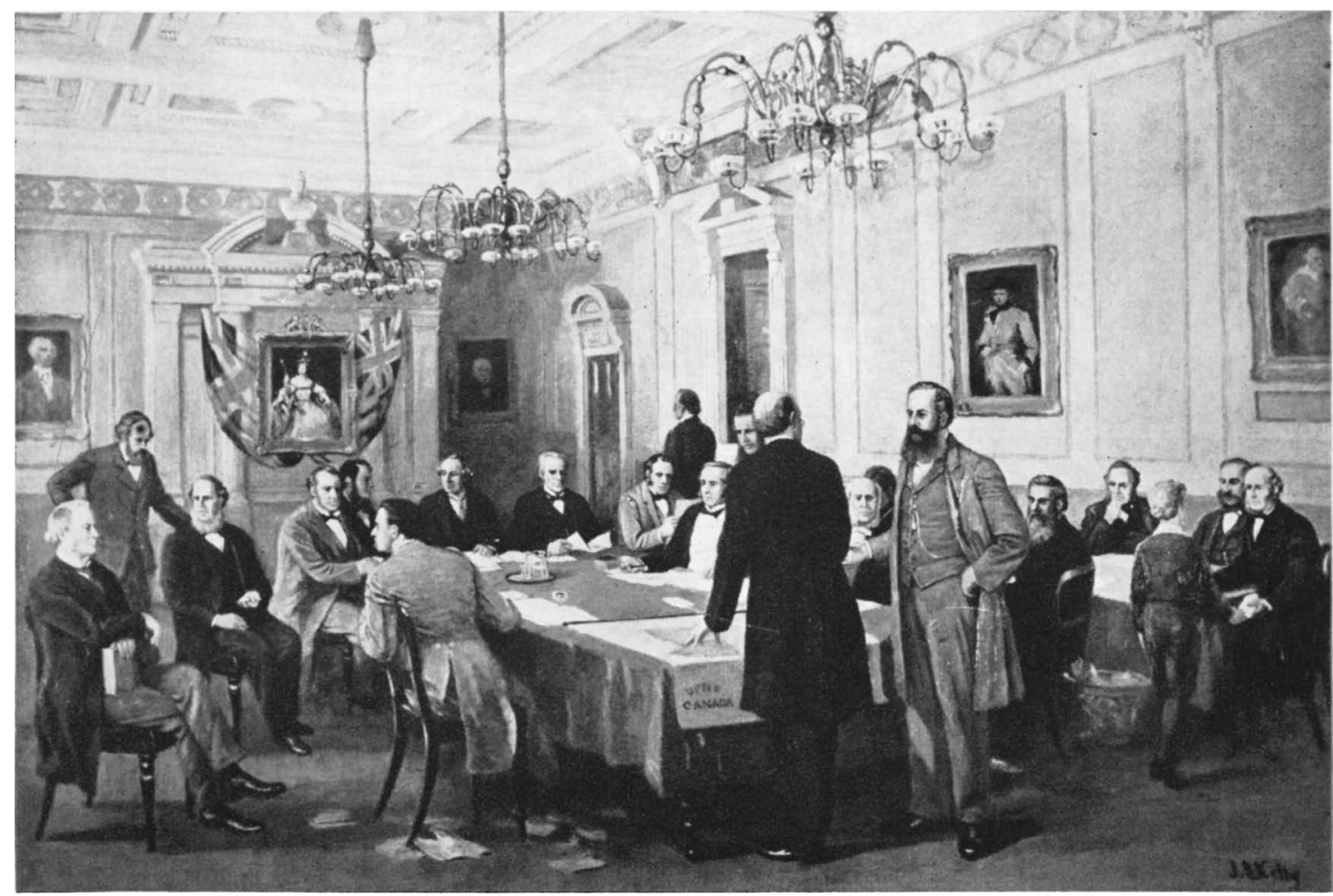

Courtesy Confederation Life Association

THE FATHERS OF CONFEDERATION, LONDON, 1866

(See key on page 525) 


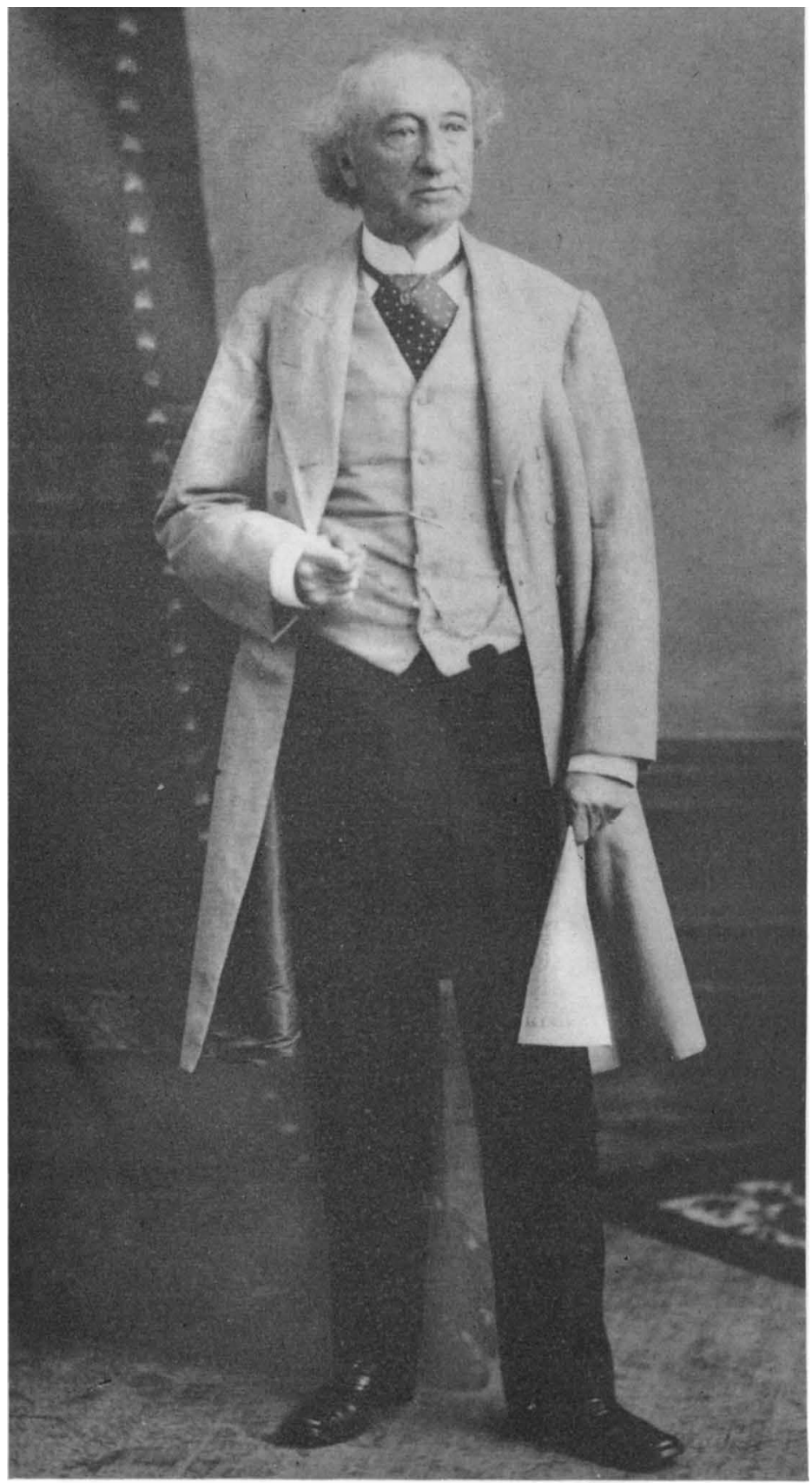

Public Archives of Canada

JOHN A. MACDONALD 


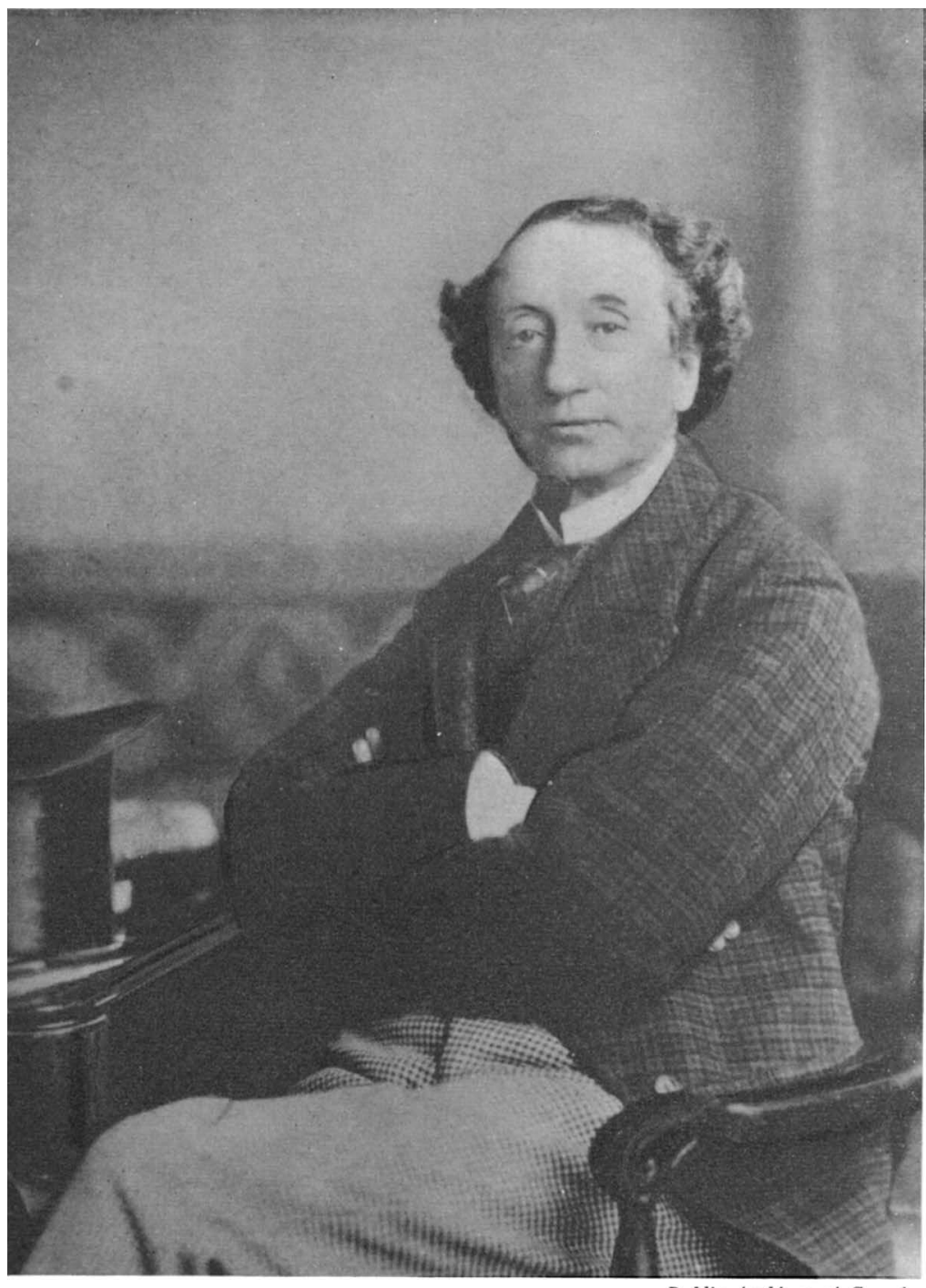

Public Archives of Canada

JOHN A. MACDONALD 


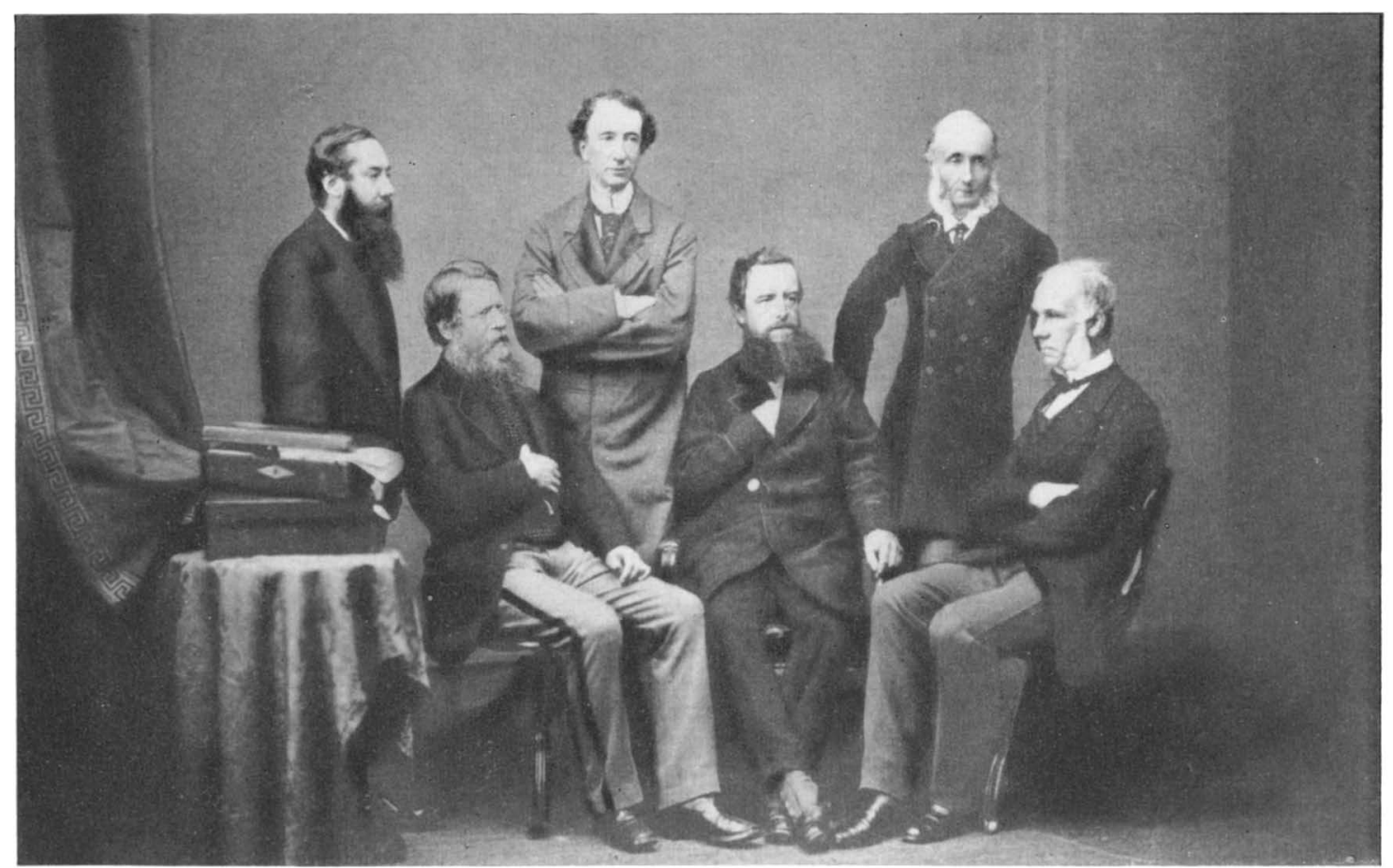
SECRETARY TO THE BRITISH COMMISSIONERS SIR STAFFORD NORTHCOTE

JOHN A. MACDONALD EARL DE GREY AND RIPON
Public Archives of Canada

Public Archive
BERNARD

SIR EDWARD THORNTON

THE BRITISH HIGH COMMISSIONERS, WASHINGTON, 1871 


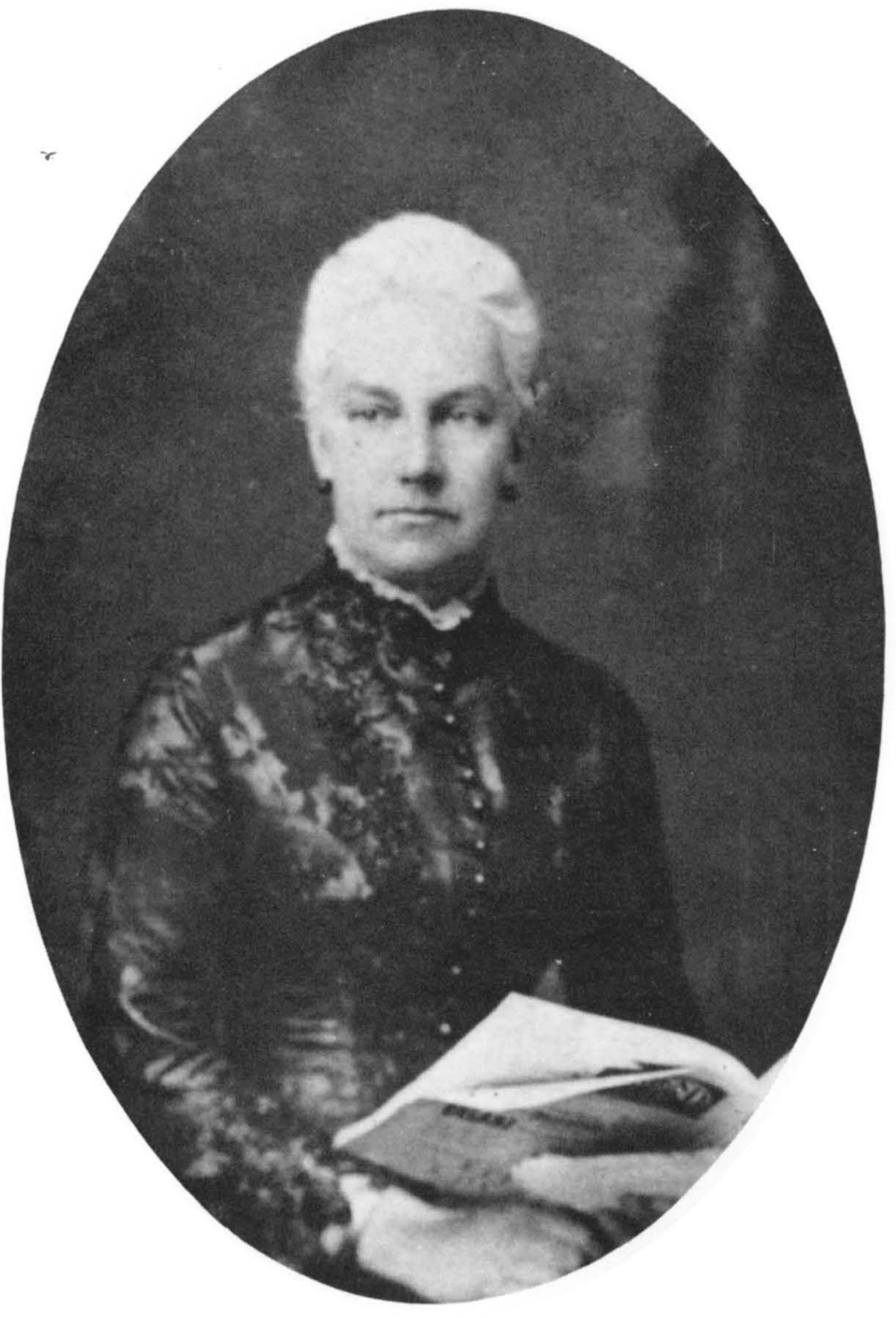

LADY MACDONALD

Public Archives of Canada 


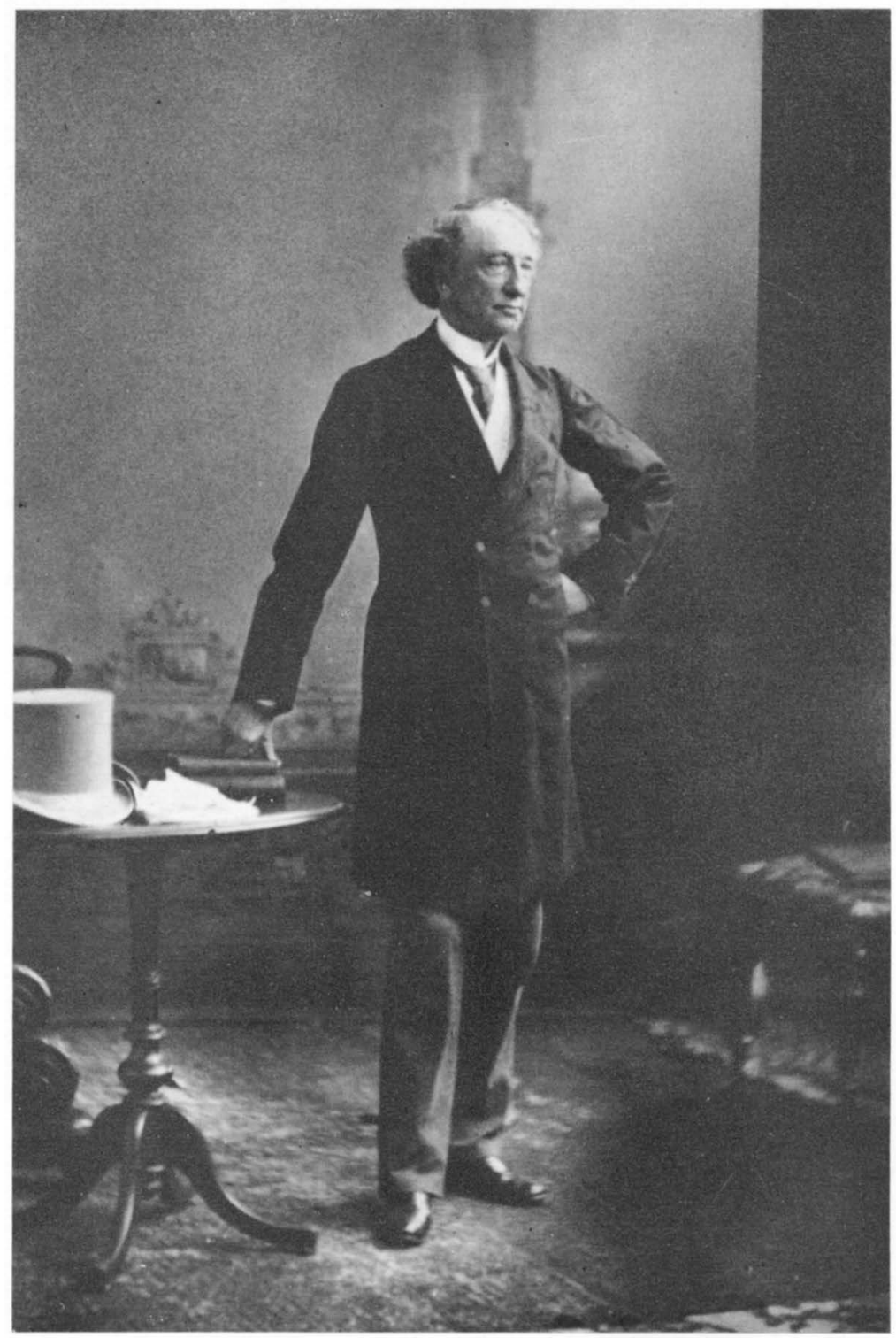

Public Archives of Canada

JOHN A. MACDONALD 


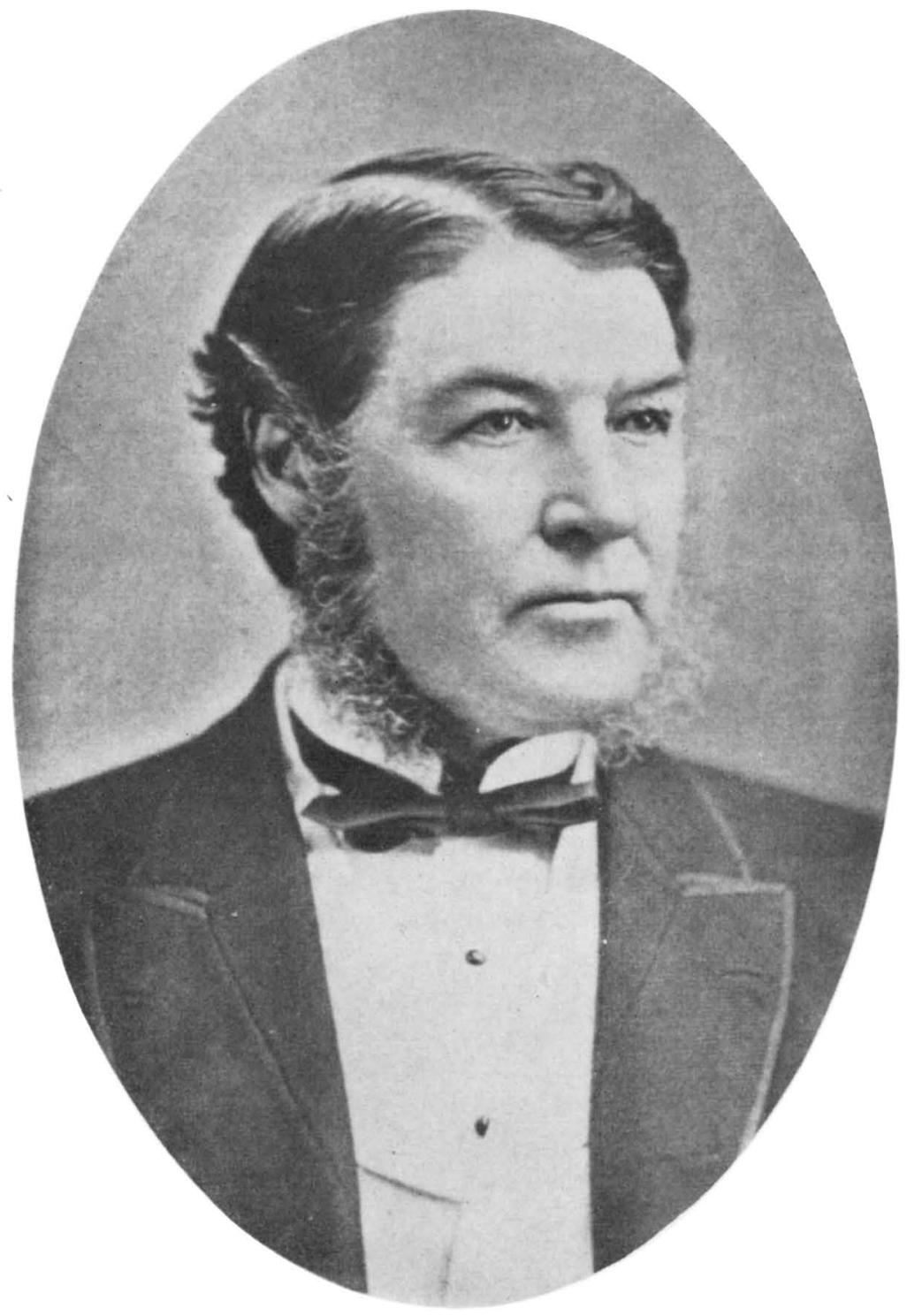

SIR CHARLES TUPPER

From Tupper's Recollections of 


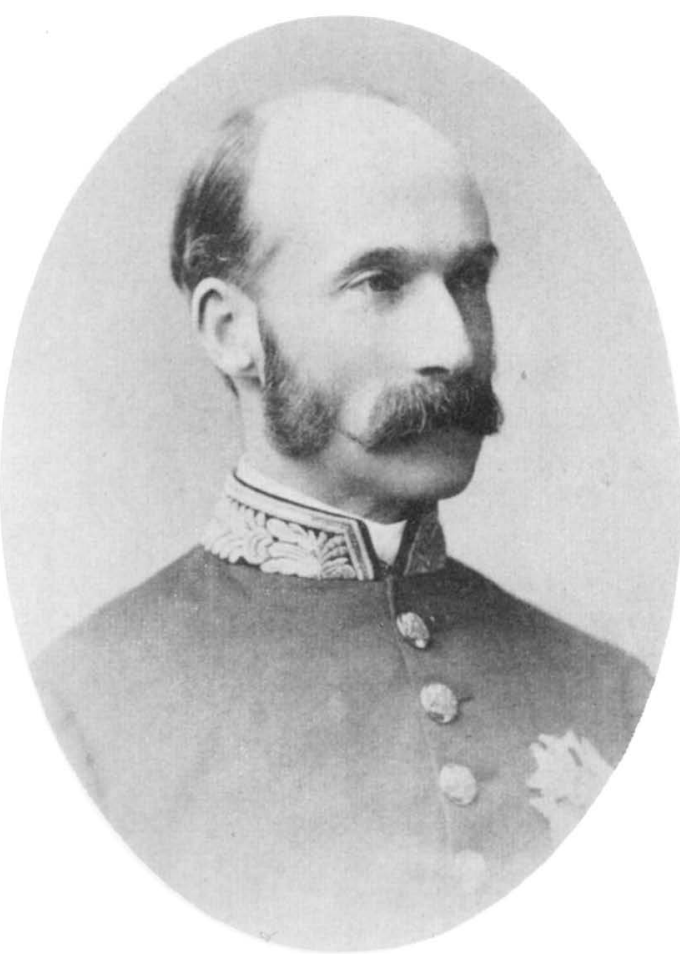

THE MARQUESS OF LANSDOWNE

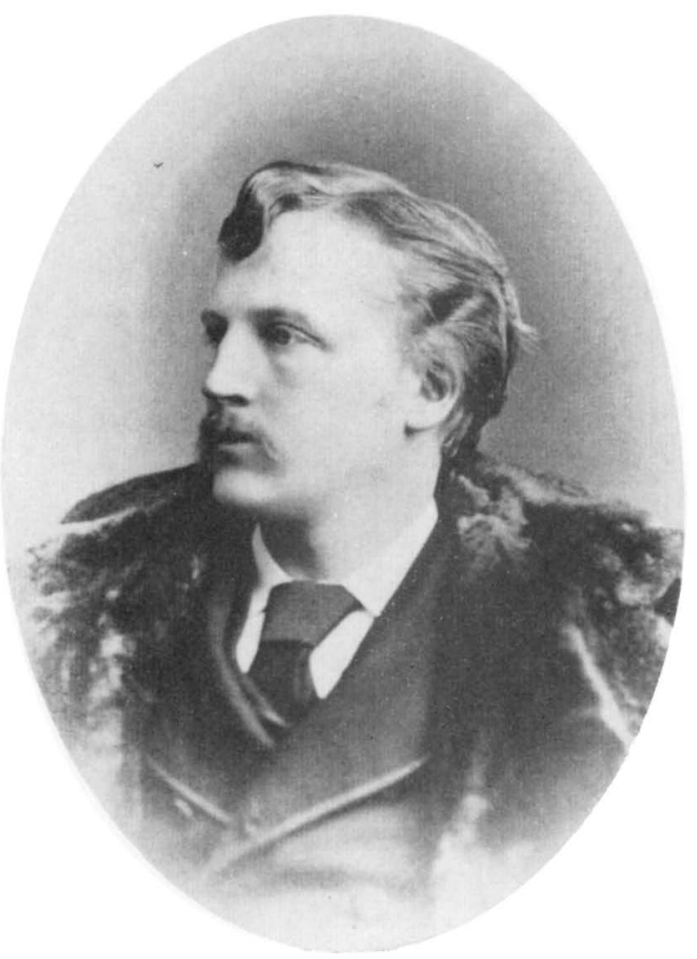

THE MARQUESS OF LORNE 


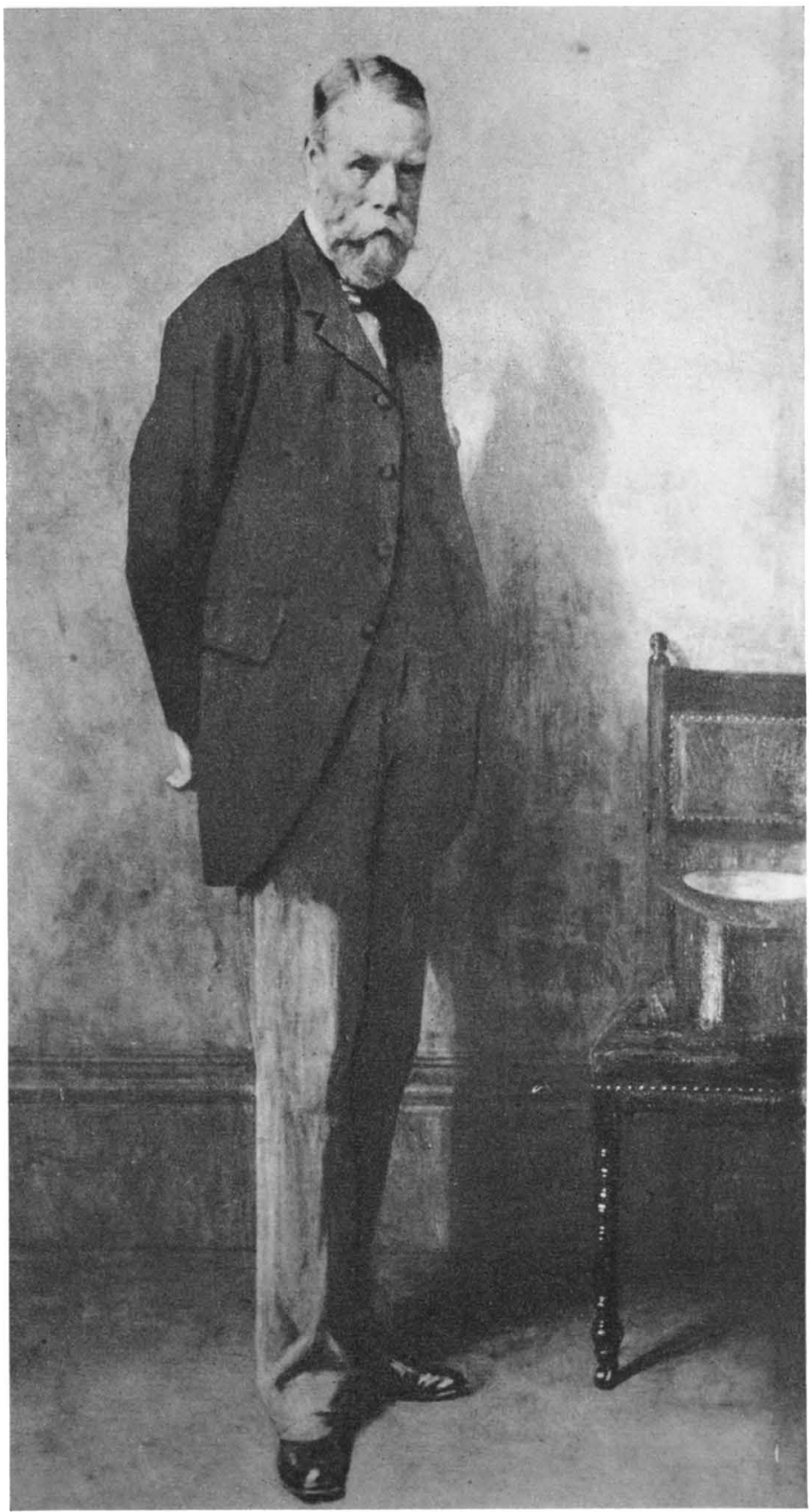

Canadian Pacific Railway

SIR GEORGE STEPHEN 


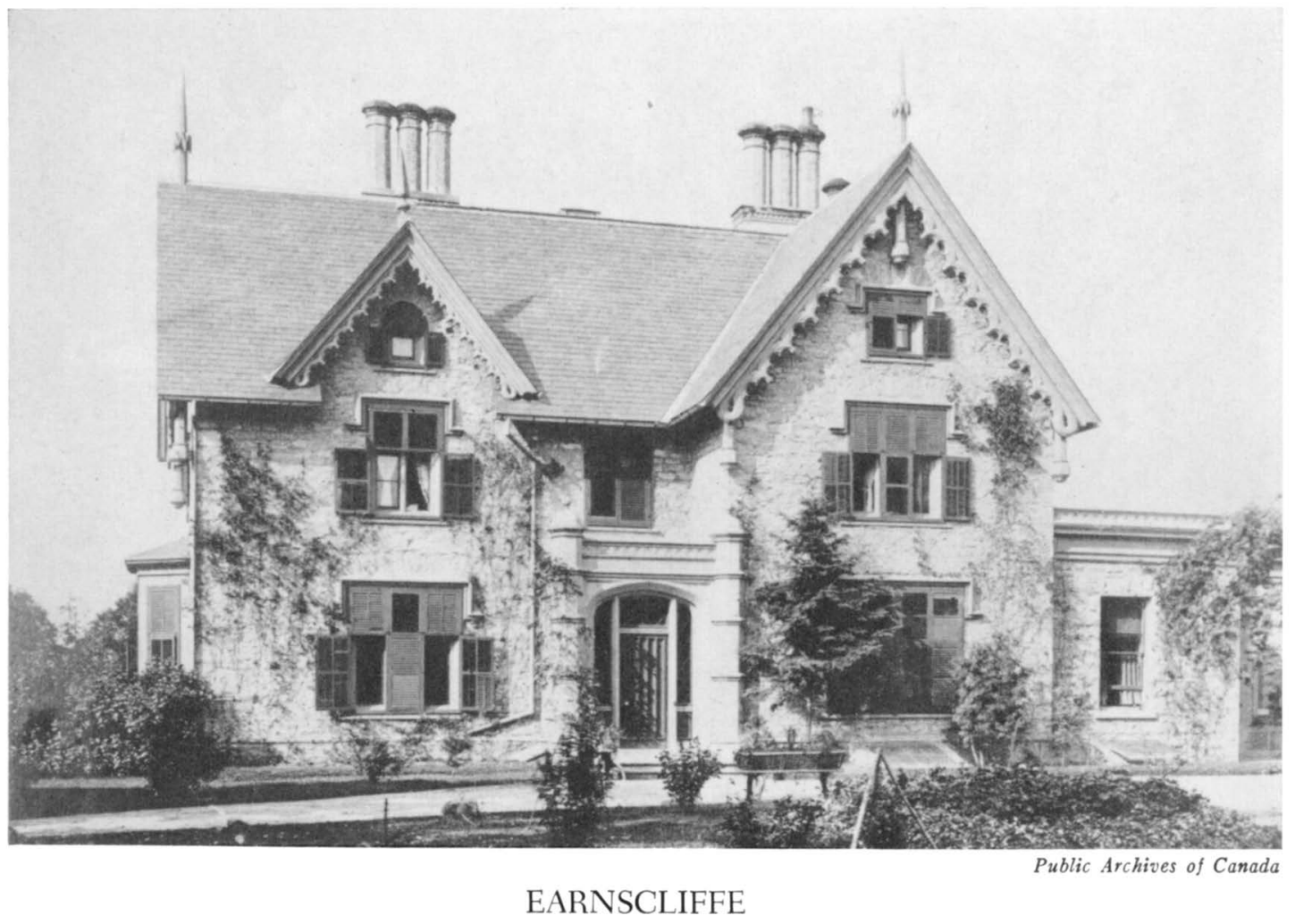




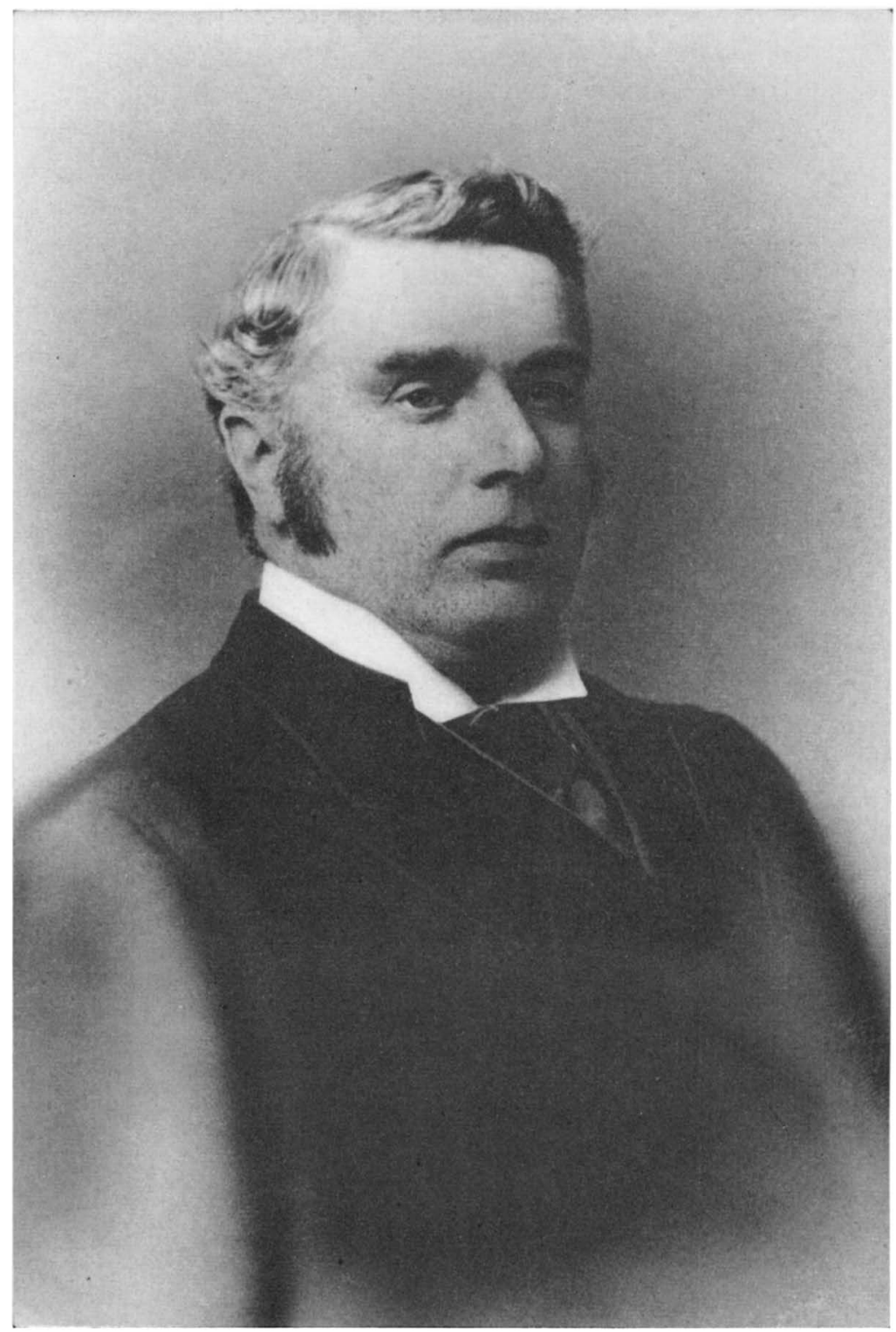


John A. Macdonald

***

The Young Politician 
This page intentionally left blank 


\section{TO}

HAROLD ADAMS INNIS 
This page intentionally left blank 